I thank the Commonwealth Institute of Entomology for its help in identifying the Eotetranychus species.

Section of Entomology,

W. R. INGRAM

Kawanda Research Station,

Department of Agriculture, Uganda.

'Michelmore, A. P. G., Rec. Invest. Dep. Agric. Uganda, No. 3 (195052), 51 (1954)

${ }^{2}$ Pearson, E. O., The Insect Pests of Cotton in Tropical Africa (Emp. Cotton Growing Corp. and Commonwealth Inst. Fnt., 1958).

s Ingram, W. R., Bull. Ent. Res:, 51, 577 (1960).

4 Baker, E. W., and Pritchard, A. E., Hilgardia, 29, 455 (1960).

${ }^{5}$ Robinson, D. M., Nature, 189, 857 (1961).

- Coaker, T. H., Rep. Exp. Stas. Emp. Cotton Growing Corp., 1956-57, Namulonge (1957).

' McKinlay, K. S., E. Afric. Agric. J., 25, 28 (1959).

\section{Anæsthesia and the Action of DDT on Anopheles Larvæ}

DR. J. C. Jones" has reported that "anæsthesia ... interferes in some important way with the obtainment of a lethal dose of DDT" by larvæ of Anopheles quadrimaculatus Say. If this effect were involved. with the metabolic processes of the insect, one might make a case for the intriguing concept of 'active' uptake of this poison. If, however, the effect is simply one of producing a lower exposure to the insecticide by decreasing the physical activity of the larvæ, it is, obviously, worth no further investigation. On the basis of the following evidence: ". . . anæsthetized larvæ which are drawn about within the [DD'T] suspension by cardboard tips are entirely comparable to those left completely quiescent", Jones ruled out the lattor possibility.

Since the hypothesis of 'active' uptake is an attractive one, and has generally been neglected, we have endeavoured to expand Jones's work. It can, indeed, be shown that fourth-stage larvæ of $A$. quadrimaculatus are protected from the insecticidal effects of DDT by the action of any of several anæsthetics (Table I). Further experimentation, however, occasions our assertion that this effect is, in spite of Jones's views to the contrary, a physical one.

Table 1. EFFects of ANesthetics on INSECTICIDAL ACTIVITY of

\begin{tabular}{|c|c|c|c|}
\hline \multirow[b]{2}{*}{ (1) } & \multirow[b]{2}{*}{$\begin{array}{r}\text { Ether-DDT } \\
\text { DDT }\end{array}$} & \multicolumn{2}{|c|}{$\underset{2 t}{\text { Alive }} \underset{h^{*}}{\text { Dead }}$} \\
\hline & & $\begin{array}{r}15 \\
0\end{array}$ & $\begin{array}{r}5 \\
20\end{array}$ \\
\hline & Ether-water & 18 & 2 \\
\hline (2) & $\begin{array}{r}\text { CO-DDT } \\
\text { DDT }\end{array}$ & $\begin{array}{r}15 \\
7\end{array}$ & $\begin{array}{r}5 \\
13\end{array}$ \\
\hline & $\mathrm{CO}_{3}$-water & 18 & 2 \\
\hline
\end{tabular}

(1) 20 larvæ immersed in 3.5 per cent ether in water for $10 \mathrm{~min}$, washed twice for 2 min with water, exposed to DDT (4 mg of $p p$, DDT dissolved in $4 \mathrm{ml}$. of acetone and suspended in $100 \mathrm{ml}$. water) for $10 \mathrm{~min}$, washed twice for 2 min with water, and placed into individual shallow water-flled containers for $24 \mathrm{~h}$ at $80^{\circ} \mathrm{F}$.

(2) 20 larvæ exposed to carbon dioxide-saturated water for $10 \mathrm{~min}$ then placed in carbon dioxide-saturated DDT (made up as above) for $10 \mathrm{~min}$, washed twice for $2 \mathrm{~min}$ with water, and incubated as above. Each result is an average of two replicates of 20 individuals.

Four groups of twenty larvæ were anæsthetized with carbon dioxide by bubbling the gas for $10 \mathrm{~min}$ through water in which they were immersed. Each group was then transferred to a separate container of DDT of sufficient strength to kill within $24 \mathrm{~h}$ 75-100 per cent of the animals exposed to it for 10 min. Group 1 was permitted to remain completely motionless for the 10-min interval; carbon dioxide was bubbled for $3 \mathrm{~min}$ through the DDT suspension in which group 2 had been placed, after which these larvæ were left undisturbed for the remaining $7 \mathrm{~min}$ (although completely anæsthetized, they were in motion in DDT for 3 of the $10 \mathrm{~min}$ ); group 3 was kept in motion by the bubbles of carbon dioxide for $7 \mathrm{~min}$, then left immobile for $3 \mathrm{~min}$; group 4 was disturbed for the whole period. The experiment was completely carried out in an atmosphere of carbon dioxide, so there was no possibility of any larva becoming active during the time it was undisturbed by the bubbling gas. Table 2 clearly shows that larvæ which are kept in flux are unprotected by carbon dioxide even though metabolically torpid. To substantiate this, an experiment was done in which larvæ were anæsthetized with ether and subsequently stirred vigorously in a DDT solution while still in a flaccid state. The results obtained with this anæs. thetic were the same as those reported above.

Table 2. EFFects OF MOVEMEN'T OF ANESTHETIzed LARVA ON ACTrVITY OF DDT

$\begin{array}{cr}\begin{array}{cc}\text { Alive } \\ \text { at }\end{array} & \begin{array}{c}\text { Dead } \\ \text { h }\end{array} \\ 13 & 7 \\ 6 & 13 \\ 3 & 17 \\ 2 & 18 \\ 0 & 20\end{array}$

(1)-(4). Four groups of 20 larvæ exposed to carbon dioxide, as in Table 1 , section 2 .

* Each result is an average of two replicates of 20 individuals.

Whether the protective effect of anæsthesia is attributable to the very low rate of diffusion of DDT, limiting the amount of contact with the immobile larval surface in the time period involved, or to the decreased larval surface exposed as a result of cessa. tion of movement, is not known at this time. In accord with the overall findings, however, is the work of Lewis ${ }^{2}$, who has shown that Risella oil spreads quite rapidly over the cuticle of blowflies only when they are moving, and assigns this effect to elastic submicroscopic movements in the cuticular surface associated with walking.

This work was partially supported by grant No. $A I-0286703$ from the U.S. National Institutes of Healtb.

\section{S. Friedman *}

J. Chalkley

Ross Institute of Tropical Hygiene,

Keppel Street,

Gower Street,

London, W.C.1.

* On leave from the Department of Entomology, Purdue University, Lafayette, Indiana.

${ }^{1}$ Jones, J. C., Nature, 182, 723 (1958).

${ }^{2}$ Lewis, C. T., Nature, 198, 904 (1962).

\section{MICROBIOLOGY}

\section{Origin of the Endoplasmic Reticulum}

To propose a mechanism of origin of the endoplasmic reticulum based on a study of yeast cytology may seem presumptuous because there is no field in which so many different opinions prevail. The variety of opinions have arisen because yeasts, like all acellular (single-celled) organisms, manifest a maximal diversity of internal organization, and a limited number of these manifestations are considered by different individuals to be typical, and because yeast cytology has engaged the interest of those who are primarily interested in yeast and only secondarily interested in cytology. But the fact that almost the entire internal organization of a small $(5 \mu)$ structure 